\title{
Influence of Organic and Organo-Mineral Fertilizers on Growth and Fruit Yield of Eggplant on Acidic Soil
}

\author{
Yéboua F. Kouassi ${ }^{1}$, Akré H. D. Abobi ${ }^{2}$, Kouadio H. Assié ${ }^{1}$, Wowo A. Koné ${ }^{3} \&$ Kouassi T. P. Angui ${ }^{1}$ \\ ${ }^{1}$ Training and Research Unit of Environmental Sciences and Management, NANGUI ABROGOUA University, \\ Abidjan, Côte d'Ivoire \\ ${ }^{2}$ Training and Research Unit of Agroforestry, Jean Lorougnon Guédé University, Daloa, Côte d'Ivoire \\ ${ }^{3}$ Training and Research Unit of Nature Sciences, NANGUI ABROGOUA University, Abidjan, Côte d'Ivoire \\ Correspondence: Yéboua F. Kouassi, Training and Research Unit of Environmental Sciences and Management, \\ NANGUI ABROGOUA University, Abidjan, Côte d'Ivoire. Tel: 225-07-0714-6743. E-mail: fyebouak@yahoo.fr
}

Received: August 24, 2021

doi:10.5539/jas.v13n12p61

\author{
Accepted: October 3, $2021 \quad$ Online Published: November 15, 2021 \\ URL: https://doi.org/10.5539/jas.v13n12p61
}

\begin{abstract}
Eggplant is a very important vegetable and economic resource crop for populations in urban areas of developing countries. Its cultivation, on acidic coastal soils of Côte d'Ivoire, presents several edaphic constraints. This study aims to assess the effects of organic fertilizers and an organo-mineral fertilizer, as compared to mineral fertilizers, on the growth and eggplant yield on an acid soil. The experiment was carried out in a randomized Fisher block, with 4 treatments and a control repeated 3 times. Treatments consisted of organic and organo-mineral fertilizers, a liquid organic fertilizer and a mineral fertilizer application. Application rates of organic and organo-mineral fertilizers were $17.5 \mathrm{t} \mathrm{ha}^{-1}$. The liquid organic fertilizer rate was $1 \mathrm{~L}$ per $200 \mathrm{~L} \mathrm{ha}^{-1}$ of water. As for the mineral fertilizer, the formula 0-23-19 and urea (46-0-0) were used, bringing rates of $138 \mathrm{~kg} \mathrm{ha}^{-1}(\mathrm{~N}), 65.35 \mathrm{~kg} \mathrm{ha}^{-1}\left(\mathrm{P}_{2} \mathrm{O}_{5}\right)$ and $54 \mathrm{~kg} \mathrm{ha}^{-1}\left(\mathrm{~K}_{2} \mathrm{O}\right)$. The organo-mineral fertilizer used produced the best effects. Very highly significant $(\mathrm{p}<$ 0.001 ) growth, such as plant height and collar diameter, were 52.69 and $1.49 \mathrm{~cm}$, respectively, 90 days after transplanting. Concerning yield, statistical analysis showed highly significant differences $(p<0.01)$ between treatments. The highest fruit yield $\left(20.87 \mathrm{t} \mathrm{ha}^{-1}\right)$ was recorded in mineral fertilizer plot, but not significantly different from those of plots with organo-mineral $\left(17.55 \mathrm{t} \mathrm{ha}^{-1}\right)$ and organic $\left(16.66 \mathrm{t} \mathrm{ha}^{-1}\right)$ fertilizers. Organo-mineral fertilizers, based on highly enriching organic materials, are capable to contribute to a lasting improvement in the practice of this crop.
\end{abstract}

Keywords: eggplant, growth, yield, organic fertilizer, organo-mineral fertilizer, urban agriculture

\section{Introduction}

Eggplant (Solanum aethiopicum) is a tropical plant that is among the ten most consumed vegetables in the world. It plays an important role in Africa, mostly in the subtropical regions. It is used to fight malnutrition, like the majority of fruits and vegetables crops (Olasantan, 2007). Many poor people in urban and peri-urban areas, especially women, live on income from the production and marketing of eggplant. The income improves the living conditions of households, especially at certain periods of the year when other sources of income dwindle (Fondio et al., 2016; Opitz et al., 2016).

Among the most cultivated and consumed vegetables in Côte d'Ivoire, eggplant ranks third after tomatoes and onions. From $60000 \mathrm{t}$ in 2004, its production reached $130000 \mathrm{t}$ in 2020 (Fondio et al., 2016). But, despite this increase, local production need is insufficient because of soil degradation that causes low yield. Unfortunately, soils fertility decreases over the years due to overexploitation which does not leave room for fallow (Fondio et al., 2013; Chikere-Njoku, 2019). Thus, soil restoration, using both organic (Mahmoud and Soliman, 2017; Koffi et al., 2018; Popoola et al., 2018) and mineral fertilizers (Abou-Sreea et al., 2017; Nath et al., 2018), is a must.

Eggplant cultivation on coastal sandy soils is an unusual practice due to a low fertility (Fondio et al., 2013; Chikere-Njoku, 2019). Therefore, it appears important to introduce this crop to this area by adopting cultivation practices that are likely to improve soil fertility under friendly environmental conditions. 
The study aims to evaluate the effects of two organic and one organo-mineral fertilizers, as compared to mineral fertilizers, on the growth parameters and the fruit yield of "Klongbo", a local eggplant variety, on an acidic sandy soil in the Abidjan District.

\section{Materials and Methods}

\subsection{Study Area}

The study was conducted at the Nangui Abrogoua University campus experiment site, in Abidjan, with $4^{\circ} 00^{\prime} 41.5^{\prime \prime}$ $\mathrm{W}$ and $5^{\circ} 23^{\prime} 16.4^{\prime \prime} \mathrm{N}$ as geographical coordinates (Figure 1). The soils are classed as Ferralsols, Acrisols and Gleysols in the World Reference Base for soil resources (WRB). They derived from granites, shales and basic rocks (Esu et al., 2008). The climate is subequatorial, of the Attiean type, with 4 seasons, including two dry seasons and 2 rainy seasons. The longer dry season runs from December to March and the shorter one from July to August. The longer rainy season stretches from April to June and the short one from September to November.

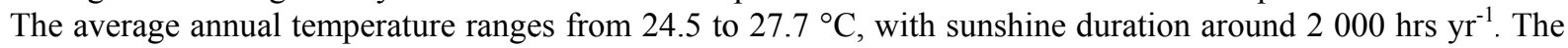
average annual rainfall is $1840.10 \mathrm{~mm}$, with a hygrometry of 80 to $90 \%$ (Koffi, 2019).

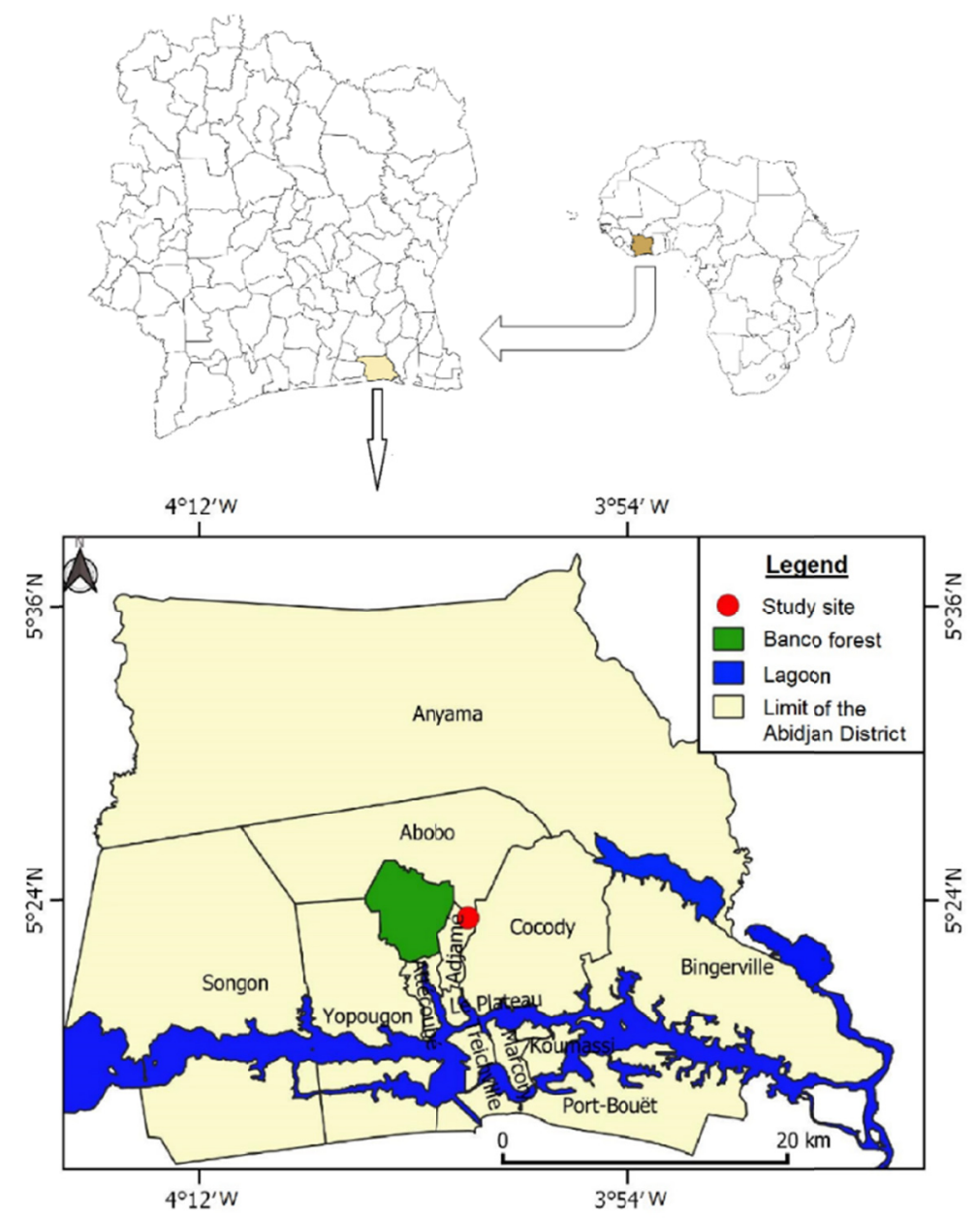

Figure 1. Study site map.

\subsection{Plant Material}

The plant material used was a local eggplant (Solanum aethiopicum) variety called Klongbo. It has good tolerance for wilt and is adapted to climatic conditions of the country. This variety has a potential yield that ranged from 5 to $24 \mathrm{tha}^{-1}$ (Fondio et al., 2016), with the first harvest occurring around 120 days after sowing. 


\subsection{Fertilizers}

Four types of fertilizers were used:

- Organic fertilizer, obtained by composting poultry manure, rice hulls and cow manure (mixed at rates of 84,9 and $7 \%$ respectively);

- Organo-mineral fertilizer, also obtained by composting poultry manure, rice hulls and cow manure $(84,9$ and $7 \%$, respectively) and mineral fertilizers providing $0.71,2.30$ and $3.24 \%$ of $\mathrm{N}, \mathrm{P}_{2} \mathrm{O}_{5}$ and $\mathrm{K}_{2} \mathrm{O}$ respectively;

- Mineral fertilizers based on urea (46-0-0) and NPK (0-23-19);

- Liquid organic fertilizer (Fertibio) obtained from the market.

\subsection{Soil Sampling}

Two soil composite samples were obtained from the 0-20 and 20-40 cm layers, mixing 4 elementary samples taken in the corners and one in the center of the plots. These samples were analyzed for physico-chemical parameters. Three other composite samples were taken from each soil layer to determine coarse elements contents.

\subsection{Soil Physical Analysis}

\subsubsection{Coarse Elements Content and Texture}

The coarse elements content (Table 1) was determined from air- dried soil samples sieved through a $2 \mathrm{~mm}$-sieve. The sieve rejects were washed, dried and weighed. The coarse elements content (\%) was determined using the following equation (Kouassi, 2012):

$$
\text { Coarse elements content }=\frac{\text { Mass of sieve residue }}{\text { Total mass of air-dried soil }} \times 100
$$

Soil texture (Table 1) was obtained through sedimentation using the Robinson-Kohn pipette method and the textural triangle to determine soil textural class (Kouassi et al., 2021).

\subsubsection{Bulk Density}

Soil bulk density (Table 1) was determined using the cylinder method. Soil samples were dried in an oven at $105^{\circ} \mathrm{C}$ for 24 hours and then weighed. The bulk density was obtained using the following formula (Jabro et al., 2020; Oumer et al., 2020; Stevens et al., 2020):

$$
\mathrm{BD}=\frac{\mathrm{M}_{\mathrm{s}}}{\mathrm{V}_{\mathrm{ss}}}
$$

Where, $\mathrm{M}_{\mathrm{s}}$ : Mass of dry soil sample $(\mathrm{g})$; $\mathrm{V}_{\mathrm{ss}}$ : Volume of soil sample $\left(\mathrm{cm}^{3}\right)$.

Table 1. Initial soil physical characteristics

\begin{tabular}{lll}
\hline \multirow{2}{*}{ Parameters } & \multicolumn{2}{c}{ Soil layers $(\mathrm{cm})$} \\
\cline { 2 - 3 } & $0-20$ & $20-40$ \\
\hline CE (\%) & 0 & 0 \\
Clay (\%) & 22 & 22.5 \\
Silt (\%) & 3.3 & 3.95 \\
Sand (\%) & 74.70 & 73.55 \\
Texture & Sandy clay loam & Sandy clay loam \\
BD $\left(\mathrm{g} \mathrm{cm}^{-3}\right)$ & 1.51 & 1.59 \\
\hline
\end{tabular}

Note. CE: coarse elements.

\subsection{Soil Physico-Chemical Analysis}

Soil $\mathrm{pH}$ was determined, using the electrometric method, in a soil solution with soil and water ratio of 1/2.5. Organic carbon and nitrogen contents were determined, using the Walkley-Black wet oxidation and Kjeldahl methods, respectively. Organic matter was determined by multiplying the carbon content by 1.724 (Mohammed et al., 2020; Iren et al., 2021). Available phosphorus content was determined using the Olsen and Dabin method (Tankou et al., 2020). Cation exchange capacity (CEC) and the exchangeable basic cations contents were determined by the ammonium acetate method at $\mathrm{pH}$ 7. Basic cations saturation rate was calculated by dividing the sum of exchangeable bases by the CEC and then multiplied by 100 (Iren et al., 2021) (Table 2). 
Table 2. Initial soil physico-chemical characteristics

\begin{tabular}{lll}
\hline \multirow{2}{*}{ Parameters } & \multicolumn{2}{c}{ Soil layers $(\mathrm{cm})$} \\
\cline { 2 - 3 } & $0-20$ & $20-40$ \\
\hline $\mathrm{pH}$ water & 3.7 & 3.7 \\
$\mathrm{OC}(\%)$ & 1.03 & 1.00 \\
$\mathrm{OM}(\%)$ & 1.78 & 1.72 \\
$\mathrm{~N}$ tot $(\%)$ & 0.09 & 0.08 \\
$\mathrm{C} / \mathrm{N}$ & 11.44 & 12.50 \\
\hline $\mathrm{P}$ ass $\left(\mathrm{ppm}^{\mathrm{N}}\right)$ & 41 & 47 \\
\hline $\mathrm{T}\left(\mathrm{cmol}_{\mathrm{c}} \mathrm{kg}^{-1}\right)$ & 14.07 & 13.30 \\
$\mathrm{Ca}\left(\mathrm{cmol}_{\mathrm{c}} \mathrm{kg}^{-1}\right)$ & 0.43 & 0.37 \\
$\mathrm{Mg}\left(\mathrm{cmol}_{\mathrm{c}} \mathrm{kg}^{-1}\right)$ & 0.22 & 0.18 \\
$\mathrm{~K}\left(\mathrm{cmol}_{\mathrm{c}} \mathrm{kg}^{-1}\right)$ & 0.01 & 0.04 \\
$\mathrm{Na}\left(\mathrm{cmol}_{\mathrm{c}} \mathrm{kg}^{-1}\right)$ & 0.08 & 0.07 \\
$\mathrm{~S}\left(\mathrm{cmol}_{\mathrm{c}} \mathrm{kg}^{-1}\right)$ & 0.74 & 0.66 \\
$\mathrm{~V}(\%)$ & 5.26 & 4.96 \\
\hline
\end{tabular}

Note. OC: organic carbon; OM: organic matter; T: cation exchange capacity; S: sum of exchangeable basic cations; V: basic cations saturation rate.

\subsection{Setting up the Test}

\subsubsection{Experimental Design}

The experimental design was a Fisher block, with 5 treatments and 3 replications, making a total of 15 square-unit plots of $2 \mathrm{~m}$ side $\left(4 \mathrm{~m}^{2}\right)$ each. Plots and blocks were spaced by $1 \mathrm{~m}$ and $1.5 \mathrm{~m}$, respectively. The treatments used are as follows:

C: control (without fertilizer); MF: mineral fertilizer; OF: organic fertilizer; OMF: organo-mineral fertilizer; LOF: liquid organic fertilizer.

\subsubsection{Fertilizer Application}

The different fertilizers, whose nutrient contents are in Tables 3 and 4, were applied to unit plots, as a cover, and plowed into the soil to a depth of 10 to $20 \mathrm{~cm}$ using a hoe.

The organic and organo-mineral fertilizers were applied in soil 7 days before transplanting. The amount applied to the soil per unit plot was $7 \mathrm{~kg}$, that's at a rate of $17.5 \mathrm{t} \mathrm{ha}^{-1}$.

Liquid organic fertilizer was applied to each plot just after transplanting and 15 days after, dissolving $0.4 \mathrm{~mL}$ in $80 \mathrm{~mL}$ of water. This corresponds to a rate of $1 \mathrm{~L}$ per $200 \mathrm{~L} \mathrm{ha}^{-1}$ of water.

Mineral fertilizer was applied into soil few hours before transplanting. Each unit plot received $113.68 \mathrm{~g}$ of mineral fertilizer $(0-23-19)$. Urea $(46-0-0)$ was applied, as a cover, at the $1^{\text {st }}, 2^{\text {nd }}$ and $3^{\text {rd }}$ months after transplanting, with $40 \mathrm{~g}$ per unit plot and per application. Thus, during the crop cycle, each plot received 0.055 , 0.026 and 0.022 units of $\mathrm{N}, \mathrm{P}_{2} \mathrm{O}_{5}$ and $\mathrm{K}_{2} \mathrm{O}$, corresponding to rates of $138,65.37$ and $54 \mathrm{~kg} \mathrm{ha}^{-1}$, respectively.

Table 3. Organic and organo-mineral fertilizers nutrient contents

Note. OM: organic matter.

\begin{tabular}{lll}
\hline Parameters & OF & OMF \\
\hline OM (\%) & 58.26 & 56.62 \\
$\mathrm{~N}$ tot $(\%)$ & 1.85 & 2.09 \\
$\mathrm{P}$ tot $(\mathrm{ppm})$ & 20600 & 25200 \\
$\mathrm{~K}(\mathrm{ppm})$ & 6223 & 10523 \\
\hline
\end{tabular}


Table 4. Mineral and liquid organic fertilizers nutrient contents

\begin{tabular}{|c|c|c|c|}
\hline \multirow{2}{*}{ Parameters } & \multicolumn{2}{|r|}{ MF } & \multirow{2}{*}{ LOF } \\
\hline & Urea & NPK (0-23-19) & \\
\hline $\mathrm{OM}(\%)$ & 0 & 0 & 12 \\
\hline $\mathrm{N}(\%)$ & 46 & 0 & 4.20 \\
\hline $\mathrm{P}_{2} \mathrm{O}_{5}(\%)$ & 0 & 23 & 1.10 \\
\hline $\mathrm{K}_{2} \mathrm{O}(\%)$ & 0 & 19 & 2.50 \\
\hline
\end{tabular}

Note. OM: organic matter.

\subsubsection{Transplantation}

Transplantation was done on May 6, 2018, 36 days after the nurseries were established, with a spacing of $1 \mathrm{~m}$ between rows and $0.5 \mathrm{~m}$ between plants on the same row. This gave 3 rows of 5 plants each per unit plot, which is a density of 37500 plants $\mathrm{ha}^{-1}$. Transplantation was done at down, followed by watering to facilitate plants recovery.

\subsection{Data Collection}

\subsubsection{Growth Parameters Assessment}

During 90 days of growth after transplantation, the height and the collar diameter of the plants were measured at 10-day intervals with a tape measure attached to a wooden stick and a caliper, respectively. Three plants were used per unit plot taken on the center line.

\subsubsection{Fruit Yield Determination}

Fruit yields were determined, from July 10 to October 23, 2018, using a one-meter square quadrat in a random fashion for each unit plot. All the fruits of the plants, which were inside the quadrat were harvested and weighed. Yields were determined using the following formula:

$$
\text { Yield }=\frac{\text { Mass of fruits } \times 10}{\text { Quadrat surface }}
$$

where, Yield $\left(\mathrm{t} \mathrm{ha}^{-1}\right)$, Mass of fruits $(\mathrm{kg})$, Quadrat area $\left(\mathrm{m}^{2}\right)$.

\subsection{Statistical Analysis}

Analysis of variance (ANOVA) was applied to data, using the $\mathrm{R}$ software, version 3.5.1 in order to assess differences between the treatments. In case of significant difference, the means were separated using the LSD test at the 5\% level. Pearson's correlation tests were also done between yield and growth parameters.

\section{Results}

\subsection{Effect of Fertilizers on Plant Growth}

\subsubsection{Plants Height}

The differences between plants height were very highly significant $(\mathrm{p}<0.001), 90$ days after transplanting (DAT). Organic and organo-mineral fertilizers plots had faster but not significantly different plant growth, with plant heights of 53.62 and $52.69 \mathrm{~cm}$ respectively, followed by those receiving mineral fertilizer $(43.19 \mathrm{~cm})$. As expected, the control plots gave the lowest height $(17.79 \mathrm{~cm})$ after 90 days of planting. Plant growth was boosted by organo-mineral, organic and mineral fertilizers, respectively, from the $20^{\text {th }}, 30^{\text {th }}$ and $50^{\text {th }}$ DAT. On the other hand, the plots that received liquid organic fertilizer and the control resulted in a slight growth during the 90 days (Figure 2). 


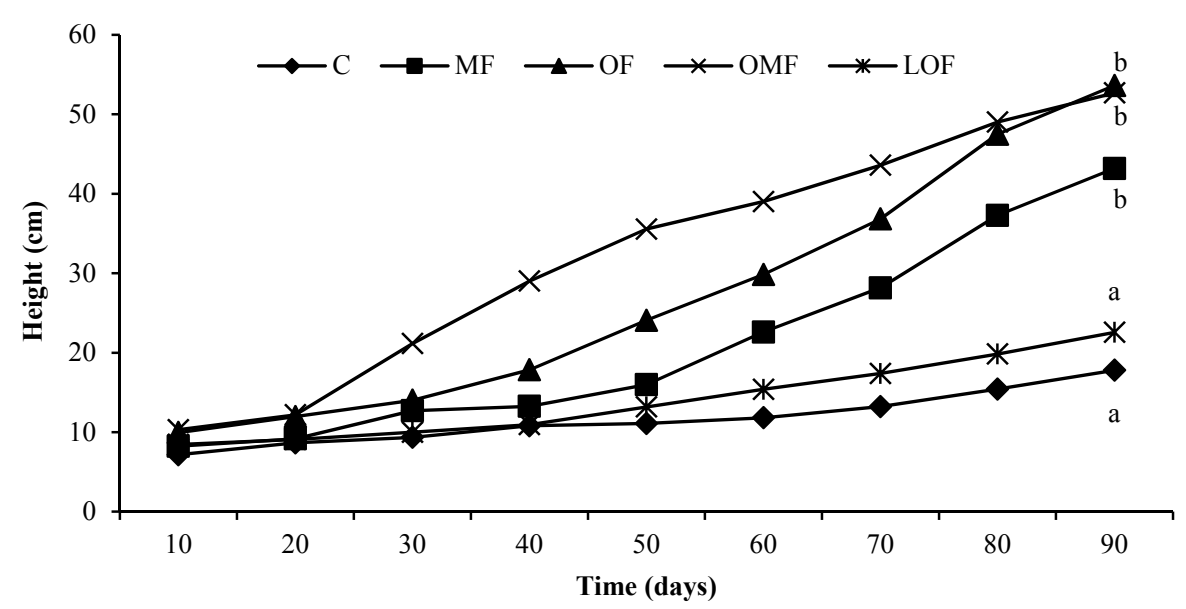

Figure 2. Time evolution of plants height

Note. C: control, MF: mineral fertilizer, OF: organic fertilizer, OMF: organo-mineral fertilizer, LOF: liquid organic fertilizer.

The heights at the $90^{\text {th }}$ DAT assigned with different letters are significantly different at the $5 \%$ level.

\subsubsection{Plants Collar Diameter}

Statistical analysis showed very highly significant differences $(\mathrm{p}<0.001)$ between the plants collar diameters at the $90^{\text {th }}$ DAT. The diameters were higher $(1.49 \mathrm{~cm})$, but not significantly different in the plots with organo-mineral fertilizer, followed by plots receiving organic fertilizer $(1.31 \mathrm{~cm})$. The control plots led to the smallest diameter $(0.66 \mathrm{~cm})$. A rapid increase in plant diameter was observed in plots with organo-mineral, organic and mineral fertilizers, at the $20^{\text {th }}, 40^{\text {th }}$ and $60^{\text {th }}$ DAT, respectively (Figure 3 ).

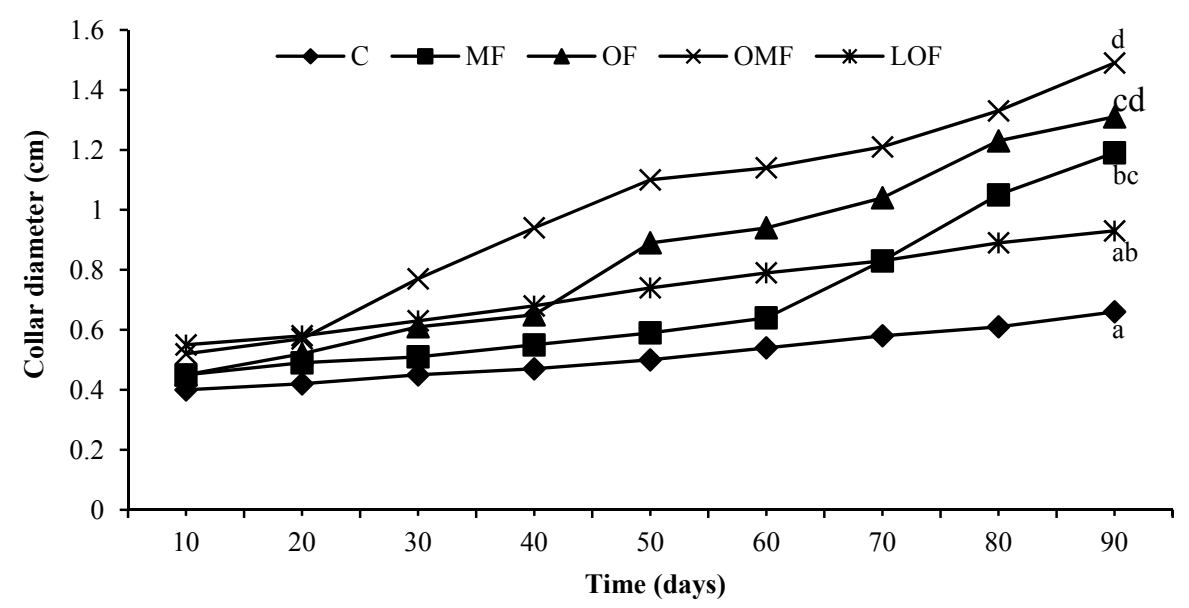

Figure 3. Time evolution of plants collar diameter

Note. C: control, MF: mineral fertilizer, OF: organic fertilizer, OMF: organo-mineral fertilizer, LOF: liquid organic fertilizer.

The collar diameters at the $90^{\text {th }}$ DAT assigned with different letters are significantly different at the $5 \%$ level.

\subsection{Effect of Fertilizers on Fruit Yield}

Statistical analysis revealed highly significant differences $(\mathrm{p}<0.01)$ between treatments. The plots with mineral, organo-mineral and organic fertilizers improved significantly eggplant fruit yield, as compared to the control. However, the highest yield was recorded in plots with mineral fertilizer $\left(20.87 \mathrm{tha}^{-1}\right)$. But, this yield was not significantly different from those of organo-mineral and organic fertilizers. The lowest yield was obtained in the control plots $\left(1.06 \mathrm{t} \mathrm{ha}^{-1}\right)$ (Figure 4). 


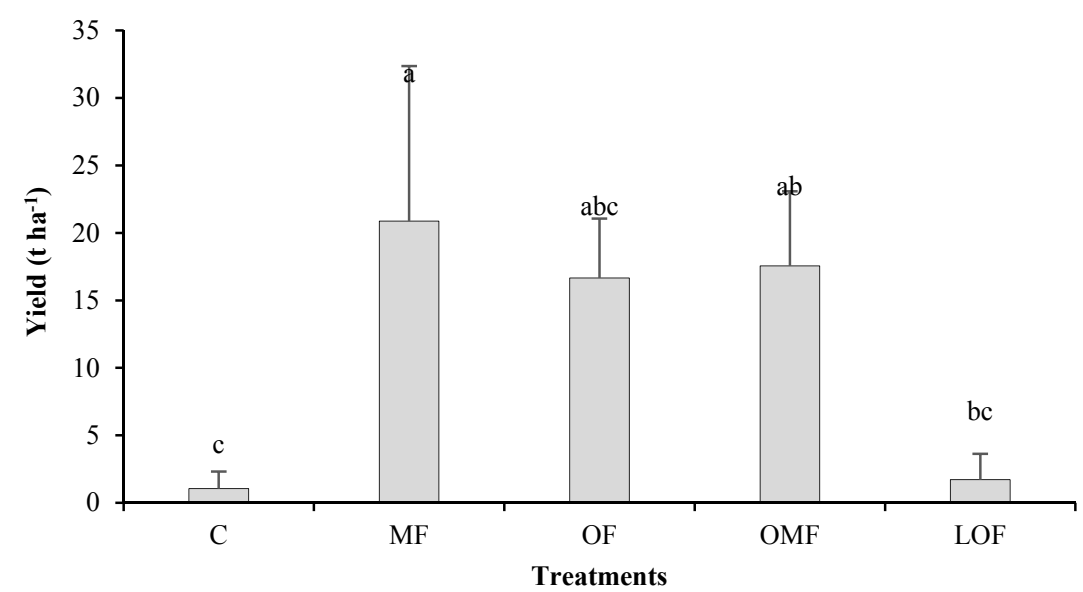

Figure 4. Eggplant yield as a function of fertilizer treatments

Note. C: control, MF: mineral fertilizer, OF: organic fertilizer, OMF: organo-mineral fertilizer, LOF: liquid organic fertilizer.

The values assigned with different letters are statistically different at the $5 \%$ level.

\subsection{Relationship Between Yield and Growth Parameters}

Statistical analysis showed positive and significant correlations between yield and plant height $(\mathrm{r}=0.80, \mathrm{p}=$ 0.001 ) (Figure 5a) and between yield and plants collar diameter $(\mathrm{r}=0.78, \mathrm{p}=0.001$ ) (Figure 5b).
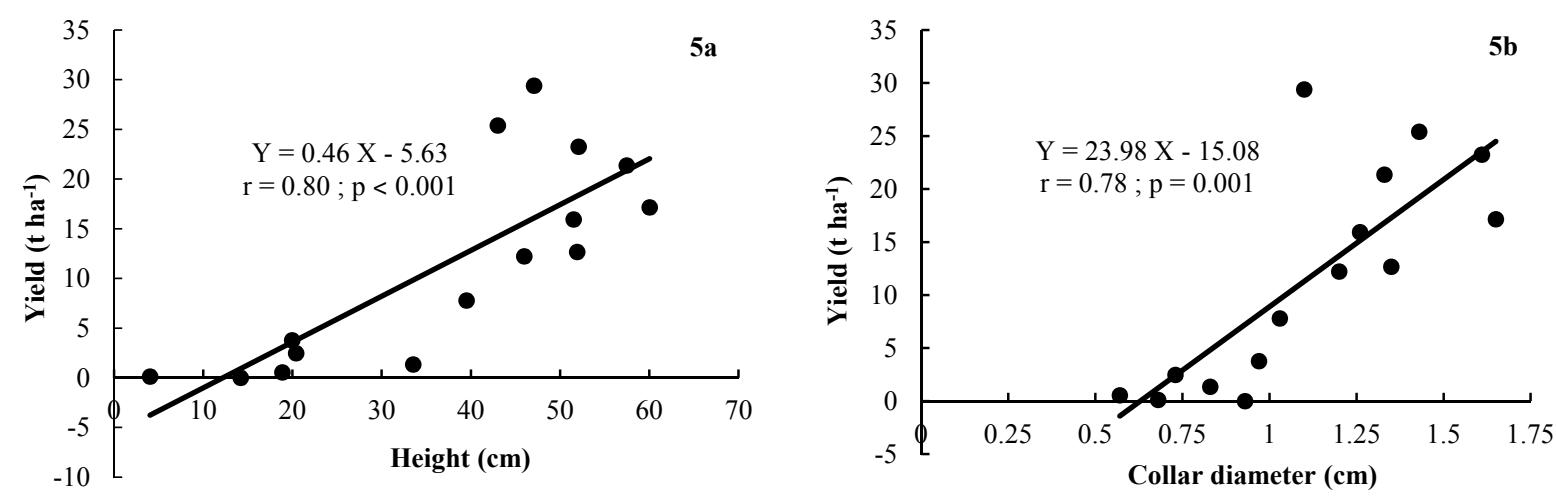

Figure 5. Correlation between eggplant yield and growth parameters

\section{Discussion}

\subsection{Soil Fertility of the Experimental Site}

The test was carried out on a soil with poor physical and chemical fertility status resulting from the site landscaping, which stripped it, thus losing its organo-mineral layer which is currently being restored under a Panicum maximum fallow. However, despite the potential of this plant species to restore soil fertility and protect it against erosion, given its liveliness and its strong rooting and dense plant biomass (Ojo et al., 2013), its fallow duration of 6 years did not raise soil fertility to a satisfactory level. The capacity of this fallow was compromised by the high sand content of the soil, which reduced its water retention capacity, with negative impacts on biological activity. Indeed, the organic fertilizers used would have improved the characteristics of these soils because most studies reported positive effects of organic fertilizers, such as biochar, on soil physical and chemical properties, as well as on soil microbial activities, even on the potential reductions of soil greenhouse gas emissions (Hui, 2021). Application of biochar, at $20 \mathrm{t} \mathrm{ha}^{-1}$, significantly increased organic matter content and $\mathrm{pH}$ in $\mathrm{Ghanaian}$ soils (Akolgo et al., 2020). Furthermore, Yin et al. (2019) and Jiang et al. (2021) showed, respectively, that biochar, 
based fertilizer increased the soil organic matter content in an acidic soil and also phosphorus use efficiency increased under straw incorporation.

\subsection{Growth Parameters}

The organic and organo-mineral fertilizers had the best effects on the growth parameters of the eggplant, in particular, the height and the collar diameter of the plants during 90 days after transplanting (DAT). This occurred from the $20^{\text {th }}$ DAT by an increased growth of these different parameters in the plots with organo-mineral fertilizer. These results were due to the combined effects of the organic and mineral fertilizers constituting the organo-mineral fertilizer. Indeed, organic fertilizer increased the organic matter content of the soil, which enhanced its ability to fix nutriments from mineral fertilizer and to hold back water for plants. Moreover, when organic fertilizers are used in a complementary way to mineral fertilization, they promote a higher amount of $\mathrm{P}$ in the soil (Tavares et al., 2021). However, unexpectedly, soil amended with compost coupled with irrigation, significantly decreased plant growth (Jarboui et al., 2021). The relatively slow growth of the plants in plots that received mineral fertilizer is due to a high rainfall, which caused the two firsts added fertilizer to leach (May, 6 and June, 6) from root zone to deeper soil horizons. For this reason, farmers in Nigeria urged to use of organic fertilizers, such as poultry droppings and cow dung, instead of mineral fertilizers (Mukhtar et al., 2021).

\subsection{Fruit Yields}

Mineral, organic and organo-mineral fertilizers significantly improved eggplant yield, as compared to the control. This justifies the strong positive correlations observed between yield and plant growth. However, the plots that received mineral fertilizers were the most productive, despite plant growth retardation caused by the loss through fertilizer leaching. The last fertilizer application, which took place during plants development, boosted production, as compared to other fertilizers. On the other hand, $60 \mathrm{~kg} \mathrm{ha}^{-1}(\mathrm{~N})$ and $2.5 \mathrm{~kg} \mathrm{ha}^{-1}(\mathrm{Zn})$ rates resulted in an optimum maize-grain yield (Afolabi et al., 2020). The yields of plots with organic and organo-mineral fertilizers were lower, but not more significantly than those of plots that received mineral fertilizer. Thus, one can argue that the rate of the organic fertilizer was low and the contents of nutrients in the organo-mineral fertilizer were also low to cover the entire crop cycle. But, above all, given soil low initial organic matter and high sand contents, the resulting low biological activity is responsible for the low mineralization observed of the added organic fertilizers. In other works, the best yield performance of Sesame was achieved with $1.5 \mathrm{t} \mathrm{ha}^{-1}$ of organo-mineral fertilizer and thus is recommended for optimum production of this crop (Oloniruha, 2021). Moreover, Hui (2021) and Islam et al. (2021) found that biochar and plastic mulches applications in Olericulture had a positive effect on fruit yield.

\section{Conclusion}

The study aimed to assess the effects of organic, organo-mineral and mineral fertilizers on growth and fruit yield of a local eggplant variety on an acidic soil. It showed that soils that received organic and organo-mineral fertilizer at a rate of $17.5 \mathrm{tha}^{-1}$ had the best plant growth during the cropping cycle. However, the highest yield was obtained with mineral fertilizer, as compared to organic and organic-mineral fertilizer. Among the fertilizers used, liquid organic fertilizer had the lowest effects. Thus, if an increase of organic and organo-mineral fertilizers rate is necessary to improve eggplant productivity, preferring more enriching organic materials in fertilizer production could promote organic fertilizer use at the expense of mineral fertilizers.

\section{References}

Abou-Sreea, A. I. B., Yassen, A. A. A. A., \& El-Kazzaz, A. A. A. (2017). Effects of iron (ii) sulfate and potassium humate on growth and chemical composition of Coriandrum sativum L. Int. J. Agric. Res., 12, 136-145. https://doi.org/10.3923/ijar.2017.136.145

Afolabi, S. G., Ewulo, B. S., Aiyelari, O. P., \& Adeyemo, A. J. (2020). Varietal response of maize to nitrogen and zinc fertilizer in Minna, southern Guinea savannah of Nigeria. Journal of Agriculture and Food Sciences, 18(2), 39-53. https://doi.org/10.4314/jafs.v18i2.3

Akolgo, G., Kemausuor, F., Awafo, E., Amankwah, E., Atta-Darkwa, T., Essandoh, E., ... Maia, C. (2020). Biochar as a soil amendment tool: effects on soil properties and yield of maize and cabbage in Brong-Ahafo Region, Ghana. Open Journal of Soil Science, 10, 91-108. https://doi.org/10.4236/ojss.2020.103005

Chikere-Njoku, C. (2019). Assessment of fertility status of soils under land use types in Egbema area, Imo state, Nigeria. Journal of Agriculture and Food Sciences, 17(2), 1-13. https://doi.org/10.4314/jafs.v17i2.1 
Esu, I. E., Akpan-Idiok, A. U., \& Eyong, M. O. (2008). Characterization and classification of soils along a typical hillslope in Afikpo area of Ebonyi State, Nigeria. Nig. J. Soil Env. Res., 8, 1-16. https://doi.org/ 10.4314/njser.v8i1.52050

Fondio, L., Djidji, A. H., N'Gbesso, M. F. P., \& Koné, D. (2013). Evaluation de neuf variétés de tomate (Solanum Lycopersicum L.) par rapport au flétrissement bactérien et à la productivité dans le Sud de la Côte d'Ivoire. Int. J. Biol. Chem. Sci., 7(3), 1078-1086. https://doi.org/10.4314/ijbcs.v7i3.15

Fondio, L., N'Gbesso M. F. P., \& Coulibaly, N. D. (2016). Effect of mineral fertilization on African eggplant (Solanum spp.) productivity in Côte d'Ivoire. Journal of Agricultural Science and Technology, 6, $188-195$. https://doi.org/10.17265/2161-6264/2016.03.006

Hui, D. (2021). Effects of biochar application on soil properties, plant biomass production, and soil greenhouse gas emissions: A mini-review. Agricultural Sciences, 12, 213-236. https://doi.org/10.4236/as.2021.123014

Iren, O. B., Udoh, D. J., Ediene, V. F., \& Aki, E. E. (2021). Assessment of soil properties and the development of Lime requirement equations for some soils in South-Eastern Nigeria. Int. J. Soil Sci., 16(1), 1-12. https://doi.org/10.3923/ijss.2021.1.12

Islam, F., Quamruzzaman, A., \& Mallick, S. (2021). Effect of different mulch paper on growth and yield of different high value vegetables in Bangladesh. Agricultural Sciences, 12, 237-246. https://oi.org/10.4236/ as.2021.123015

Jabro, J. D., Stevens, W. B., \& Iversen, W. M. (2020). Comparing two methods for measuring soil bulk density and moisture content. Open Journal of Soil Science, 10, 233-243. https://doi.org/10.4236/ojss.2020.106012

Jarboui, R., Dhouib, B., \& Ammar, E. (2021). Effect of food waste compost (FWC) and its non-aerated fermented extract (NFCE) on seeds germination and plant growth. Open Journal of Soil Science, 11, 122-138. https://doi.org/10.4236/ojss.2021.112007

Jiang, B. S., Shen, J. L., Sun, M. H., Hu, Y. J., Jiang, W. Q., Wang, J., ... Wu, J. S. (2021). Soil phosphorus availability and rice phosphorus uptake in paddyfields under various agronomic practices. Pedosphere, 31(1), 103-115. https://doi.org/10.1016/S1002-0160(20)60053-4

Koffi, B. Y., Koné, A. W., Tiho, S., Kouadio, F, \& Masse, D. (2018). Does a specific location of composted poultry litter in soil influence nutrient use efficiency and vegetable production ? A Mesocosm Experiment. Journal of Agricultural Science, 10(2), 167-177. https://doi.org/10.5539/jas.v10n2p167

Koffi, E. S., Koffi, K. T., Perrin, J.-L., Séguis, L., Guilliod, M., Goné, D. L., \& Kamagaté, B. (2019). Hydrological and water quality assessment of the Aghien Lagoon hydrosystem (Abidjan, Côte d'Ivoire). Hydrological Sciences Journal, 64(15), 1893-1908. https://doi.org/10.1080/02626667.2019.1672875

Kouassi, Y. F. (2012). Influence of cultivation techniques on the soils of an industrial pineapple farm in Tiassalé, in the South-East of Côte d'Ivoire (p. 141, PhD thesis, NANGUI ABROGOUA University, Abidjan, Côte d'Ivoire). Retrieved from http://archives.uvci.edu.ci

Kouassi, Y. F., Assié, K. H., Ama, T. J., \& Angui, K. T. P. (2021). Hydrodynamic assessment of soils under continuous cultivation in the savannah zone, North of Côte d'Ivoire. Int. J. Soil Sci., 16(1), 13-19. https://doi.org/10.3923/ijss.2021.13.19

Mahmoud, A. M., \& Soliman, A. Sh. (2017). Comparative study on the influence of organic fertilizer and soil amendments on evening primrose (Oenothera biennis L.). Int. J. Agric. Res., 12, 52-63. https://doi.org/10.3923/ijar.2017.52.63

Mohammed, M., Takele, G., \& Kibret, K. (2020). Effects of physical soil and water conservation structures and slope gradients on soil physicochemical properties in west Oromia, Ethiopia. Int. J. Soil Sci., 15, 1-7. https://doi.org/10.3923/ijss.2020.1.7

Mukhtar, R. B., Inuwa, A., \& Umar, M. (2021). Evaluation of growth response of Parkia biglobosa (Jacq) under different levels of organic manures. Agro-Science, 20(1), 22-24. https://doi.org/10.4314/as.v20i1.4

Nath, A., Kashem, M. A., \& Ali, S. (2018). Growth and yield performance of boro rice (BRRI dhan58) under different fertilizer and agronomic management in wetland. Int. J. Agric. Res., 13, 53-57. https://doi.org/ 10.3923/ijar.2018.53.57

Ojo, V. O. A., Dele, P. A., Amole, T. A., Anele, U. Y., Adeoye, S. A., Hassan, O. A., ... Idowu, O. J. (2013). Effect of intercropping Panicum maximum var. Ntchisi and Lablab purpureus on the growth, herbage yield 
and chemical composition of Panicum maximum var. Ntchisi at different harvesting times. Pakistan Journal of biological Sciences, 16, 1605-1608. https://doi.org/10.3923/pjbs.2013.1605.1608

Olasantan, F. O. (2007). Vegetable production in tropical Africa: Status and strategies for sustainable management. Journal of Sustainable Agriculture, 30(3), 41-70. https://doi.org/10.1300/J064v30n03_05

Oloniruha, J. A., Ogundare, S. K., \& Olajide, K. (2021). Growth and yield of sesame (Sesamum indicum) as influenced by plant population density and organo-mineral fertilizer rates. Agro-Science, 20(1), 15-21. https://doi.org/10.4314/as.v20i1.3

Opitz, I., Berges, R., Piorr, A., \& Krikser, T. (2016). Contributing to food security in urban areas: differences between urban agriculture and peri-urban agriculture in the Global North. Agric Hum Values, 33, 341-358. https://doi.org/10.1007/s10460-015-9610-2

Oumer, M. R. H., Abdi, A. B., \& Yusuf, M. M. (2020). Biomass and Soil Organic Carbon Stocks of Woody Species at Ades Dry Afromontane Forest, South-Eastern Ethiopia. Int. J. Soil Sci., 15(1), 8-15. https://doi.org/10.3923/ijss.2020.8.15

Popoola, L. T., Aderibigbe, T. A., \& Korave, K. T. (2018). Operation parameters impact on fertilizer NPK produced by anaerobic co-digestion of plantain extract and cow dung. Int. J. Agric. Res., 13, 58-64. https://doi.org/10.3923/ijar.2018.58.64

Stevens, J. J., Stevens, W. B., \& Iversen, W. M. (2020). Comparing two methods for measuring soil bulk density and moisture content. Open Journal of Soil Science, 10, 233-243. https://doi.org/10.4236/ojss.2020.106012

Tankou, C. M., Beyegue, H. D., Kouam, E. B., Essam, J. V. L. M., \& Ngouenet, A. (2020). Responses of potato (Solanum tuberosum L.) varieties to green manure. Int. J. Agric. Res., 15(1), 41-47. https://doi.org/10.3923/ ijar.2020.41.47

Tavares, R. L. M., Luciano de Oliveira, C., Lara de Assis, R., Vasconcelos de Paiva Filho, S., Camila dos Santos F., \& Boldrin, P. F. (2021). Humic Substances With Mineral Fertilization on Nutrient Availability in Irrigated Soil. Journal of Agricultural Science, 13(9), 104-111. https://doi.org/10.5539/jas.v13n9p104

Yin, D., Guo, X., Ding, G., Jin, L., Man, X., Yang, K., ... Zhang, P. (2019). Effects of biochar based fertilizer on soil nutrient content and maize yield of acidic soil in Heilongjiang Province. Advances in Bioscience and Biotechnology, 10, 133-149. https://doi.org/10.4236/abb.2019.106010

\section{Copyrights}

Copyright for this article is retained by the author(s), with first publication rights granted to the journal.

This is an open-access article distributed under the terms and conditions of the Creative Commons Attribution license (http://creativecommons.org/licenses/by/4.0/). 